\title{
Patiënten en potentialen
}

Citation for published version (APA):

Spaans, F. (2003). Patiënten en potentialen: Afscheidsrede door Prof. Dr. F. Spaans. Universiteit Maastricht. https://doi.org/10.26481/spe.20031031fs

Document status and date:

Published: 31/10/2003

DOI:

$10.26481 /$ spe.20031031fs

Document Version:

Publisher's PDF, also known as Version of record

\section{Please check the document version of this publication:}

- A submitted manuscript is the version of the article upon submission and before peer-review. There can be important differences between the submitted version and the official published version of record.

People interested in the research are advised to contact the author for the final version of the publication, or visit the DOI to the publisher's website.

- The final author version and the galley proof are versions of the publication after peer review.

- The final published version features the final layout of the paper including the volume, issue and page numbers.

Link to publication

\footnotetext{
General rights rights.

- You may freely distribute the URL identifying the publication in the public portal. please follow below link for the End User Agreement:

www.umlib.nl/taverne-license

Take down policy

If you believe that this document breaches copyright please contact us at:

repository@maastrichtuniversity.nl

providing details and we will investigate your claim.
}

Copyright and moral rights for the publications made accessible in the public portal are retained by the authors and/or other copyright owners and it is a condition of accessing publications that users recognise and abide by the legal requirements associated with these

- Users may download and print one copy of any publication from the public portal for the purpose of private study or research.

- You may not further distribute the material or use it for any profit-making activity or commercial gain

If the publication is distributed under the terms of Article $25 \mathrm{fa}$ of the Dutch Copyright Act, indicated by the "Taverne" license above, 
Patiënten en potentialen 


\section{Colofon}

Omsloghustrote: ontwerp wan de outeur

Basisontwerp en realisatie: Unigrophic, Universteit Madstricht

Toelichting bij de sllustratie op voorzijge

Te buginnen uiterst links en vervolgens met de wijzers van de klok mee zijn weergegeven:

- vher kanalen van een ELG-fragment bij een patiênt met epilepsie.

- een door lichtstimulathe opgewekte nethespotentiaal afgeleid met een lenselektrode

- $3 / 5$ ec zenumstimulatile veroorzaakt het inzakken wan een spierpotentiaal (myasthenie)

- sensibele zenuwpotential met rirgelehtroden afigeleid van een winger

- ontlading wan spierwezehs waartussen een abnormaal rechtstreeths contact is ontstaan

- spontane potentialen van gedenerveerde spiervezels

- reflexmeting met oppervlakte-ellektroden bij stimulatia van cen beenzemuw

- een myotane ontlading

- gestimuleerd single-îber EMG toont neuromusculaine transmissiestoomis

- fragment van Doppler-meting aan een grote halsslagacter

" door geluidstimuli opgewekt potentialencomplex afkomstig wan de hersenstam

Alle rethen woorbehouden. Niets unt dere uitgowe mag worden verveevowdigd, opgesfagen in een geautomatiseerd gegeven bestand of openbaar gemaakt, zonder woorafgaonde schrifte like toestemming won de auteur of uitgewer. 


\section{Patiënten en potentialen}

\section{Afscheidsirede}

In verkorte vorm uitgesproken op

31 oktober 2003 te Maastricht

door

\section{Prof. Dr. F. Spaans}

Hoogleraar Klinische Neurofysiologie in de Faculteil der Geneeskunde

Universiteit Maastricht

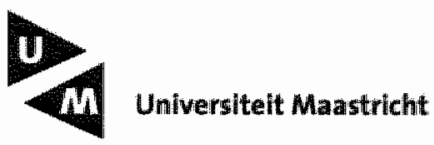




\section{Patiënten en potentialen}

\section{Mijnheer de rector magnificus, zeer gewaardeerde toehoorders.}

Voor degenen onder u die dat nog niet wisten: klinische neurofysiologie is een heel uitgebreid vakgebied. Het omvat een groot aantal technieken, bestudeert deels zeer complexe fysiologische processen en biedt diagnostische ondersteuning voor een scala van aandoeningen van zowel het centrale als het perifere zenuwsteisel en van daarmee verbonden structuren. Ook de leken onder $u$ zullen weten dat met het elektro-encefalogram (EEG) informatie over de hersenactiviteit kan worden verkregen en wellicht ook dat met behulp van elektromyografie (EMG) aandoeningen van spieren en perifere zenuwen kunnen worden opgespoord. Alleen al deze twee typen onderzoek hebben zich dermate ontwikkeld dat sommige beoefenaars zich tot een van beide hebben beperkt. Ik wil beginnen met de verschillende vormen van klinisch neurofysiologisch (KNF) onderzoek in vogelvlucht de revue te laten passeren.

\section{De elektro-encefalografie}

Dat hersenen elektrische activiteit produceren was al in 1875 bekend. De Engelsman Caton registreerde die toen rechtstreeks van de hersenschors bij konijnen en bij apen. ' In de twintiger jaren van de vorige eeuw lukte het Berger als eerste om, door de intacte schedel heen, dergelijke activiteit te registreren bij de mens. De bevindingen van deze Duitse psychiater, die ook belangstelling had voor telepathie en sterrenwichelarij, werden aanvankelijk gewantrouwd, maar nadat ze in 1934 door de Britse neurofysiologen Adrian en Matthews waren bevestigd, en vervolgens bleek dat er afwijkende patronen waren die een pathologische betekenis hadden; begon het EEG aan zijn opmars in de kliniek. Het was lange tijd de enige niet invasieve techniek waarmee informatie over hersenafwijkingen kon worden verkregen. Toen in de jaren zeventig geleidelijk aan de computer tomografie (CT-scan) beschikbaar kwam, medio jaren tachtig gevolgd door beeldvorming met behulp van magnetische resonantie (MRI), was het EEG niet meer nodig voor het opsporen van structurele lesies. Voor het aantonen van functiestoornissen is het echter tot op de dag van heden van groot belang gebleven. Dat was altijd al het geval voor de diagnostiek van epllepsie, maar in de loop van de tijd hebben zich talrijke andere toepassingsgebieden aangediend. 
Zo wordt het EEG tegenwoordig o.a. veel toegepast op couveuseafdelingen, waar bij ernstig zieke pasgeborenen, die worden beademd en war ook andere lichaamsfuncties kunstmatig worden ondersteund, het EEG vrijwel de enige meetbare parameter is om de functionele toestand van het patiëntje te beoardelen.

Bij operaties waarbij slagaders die de hersenen van bloed moeten woorzien tijdelijk worden afgesloten, wordt het EEG, walk in combinatie met andere neurofysiologische technieken, gebruikt om problemen met de hersenfunctie tijdig te signaleren. Steeds meer wordt ook het belang van continue EEG-monitoring duidelijk bij bewusteloze patiënten op intensive care afdelingen. Hiermee kumnen subklinisch verlopende eptleptische aanvallen worden onderkend, alsmede het optreden van doorbloedingsstoornissen en metabole ontregelingen van de hersenen. Het EEG speelt verder een cruciale rol wanneer in het kader van een donorprocedure moet worden vastgesteld of een patient hersendood is. Het

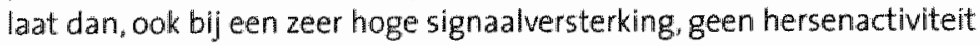
meer zien.

Registraties met rechtstreeks op de hersenschors geplaatste elektroden worden verricht om bij hersenoperaties gebieden met epileptische activiteit nauwkeurig te localiseren. We spreken daarbij van corticografie. Ook kan tijdens operaties de hersenschors rechtstreeks worden gestimuleerd om vast te stellen welke hersengebieden vitaal zijn voor belangrijke functies en derhalve niet mogen worden weggenomen. verder is het mogelijk om met diepte-elektroden specifieke gebieden in de hersenen op te zoeken. Dit wordt b.v. gedaan tijdens operaties bij patiënten die lijden aan de ziekte van Parkinson en die onvoldoende baat vinden bij medicatie. Er moet daarbij een elektrode worden aangebracht in een kleine hersenkern, waarna via een pacemaker continu hoogfrequent wordt gestimuleerd om de eigen activiteit van die kern te onderdrukken. Het traject dat de elektrode moet volgen om de betref* fende hersenkern te bereiken, wordt bepaald met behulp van een stereotaxie-frame en MRI opnamen. De elektrofysiologische registratie dient hierbij om vast te stellen of de elektrodepunt zich in de gewenste kern bevindt, dit op basis van de typische activiteit die deze kern produceert. Binnen mijn afdeling vormen intra-operatieve registraties van hersenactiviteit het aandlachtsgebied van collega Viwianne van Kranen. Zil houdt zich ook bezig met de analyse van continue EEG-video registraties die vaak dagen achtereen plaatsvinden bij patiënten waarbij de epilepsiediagnostiek problemen oplevert of die in aanmerking komen om voor hun epilepsie geopereerd te worden. 
De ontwikkelingen van de techniek hebben het niet alleen mogelijk gemaakt om EEG's met grote aantallen (tot 256) elektroden af te leiden, maar de overstap naar digitale technieken heeft ook de weg viijgemaakt voor geavanceerde analysemethoden. voor diagnostiek van slaapproblemen kan een patiënt tegenwoordig worden uitgerust met een kleine draagbare recorder waarmee via 16 kanalen informatie wordt binnen gehaald van EEG, oogbewegingen, ademhalingsexcursies, zuurstofsaturatie, spieractiviteit, lichaamshouding, etc, dit alles terwijl hij of zij de nacht in de elgen slaapkamer doorbrengt. Maar ook voor het standaard-EEG betekent de digitale techniek een enorme winst. Achteraf zijn allerlei aanpassingen mogelijk, zoals veranderingen in de schakelingen tussen elektroden, aanpassingen van de versterkingsfactor en van de mate waarin de signalen worden gefilterd, directe toepasbaarheid van een aantal analysetechnieken en, niet in de laatste plaats, elektronische opslag waardoor het ruimteprobleem dat altijd bestond bij het bewaren van op papier uitgeschreven registraties tot het verleden behoort.

Het feit dat met het EEG activiteit wordt geregistreerd van het orgaan waarin onze geestelijke capaciteiten op een of andere manier zijn opgeslagen heeft herhaaldelijk geleid tot serieuze pogingen om die verbanden duidelijk te maken. Maar ook oplichters hebben in deze materie brood gezien. Zo zijn wij een aantal jaren geleden gestuit op een pseudo-professor die bedrijven geld uit de zak wist te kloppen door ze wijs te maken dat hij het $\mathrm{IQ}$ van hun medewerkers met 10 à $30 \%$ zou kunnen verbeteren en hun geheugencapaciteit zou kunnen verdrievoudigen door via feedback training de frequentie van hur EEG-rittmes te verhogen.

\section{Elektromyografie}

Dat het functioneren van spieren en zenuwen iets met elektriciteit te maken had, werd in de tweede helft van de 18 de eeuw al duidelijk uit dierproeven van Volta, Galvani en de minder bekende Caldani. ${ }^{\text {In }} 1849$ rapporteerde de Duitse wetenschapper Emil Du Bois Reymond voor het eerst een EMG registratie van een menselijke armspier bij willekeurig aanspannen, maar een diagnostische toepassing zou nog een eeuw op zich laten wachten. Daarvoor was 0.a. eerst de introductie wan de concentrische naaldelektrode nodig (Adrian en Bronk, 1929). Dit type elektrode bleek selectief genoeg om potentialen van afzonderlijke motorische eenheden te kunnen registreren. Een geperfectioneerde 
uitwoering van deze naald is nog steeds de meest gangbare EMGelektrode.

Inmiddels waren er enkele publicaties verschenen over zenuwgeleidingsonderzoek (Hoffmann, 1910; Adrian en Lucas, 1912). Vanaf omstreeks 1948 deden naald-EMG en zenuwgeleidingsonderzoek (doorgaans samen aangeduid als 'EMG') hun intree in de kliniek. Dit onderdeel van het vak heeft zich geleidelijk dusdanig ontwikkeld, dat in diverse KNF-afdelingen, waaronder de onze, EMG het meest verrichte onderzoek is geworden.

Binnen de klinische neurofysiologie is, zoals de meestem onder $u$ weten, de elektromyografie steeds mijn speciale aandachtsgebied geweest. Waar het EEG erop is gericht om alan de hand van potentiaalschommelingen die over de intacte schedel worden gemeten uitspraken te doen over het functioneren van hersengebieden, waar tussen miljoenen zenuwcellen complexe interacties plaatsvinden, is er bij het EMG een vrijwel direct contact met zenuwen en spiervezels, waarbij de onderlinge interacties bovendien eenduidiger zijn. Zo kan door zenuwen elektrisch te stimuleren en op een ander punt de daardoor opgewekte zenuw of spierpotentialen te registreren o.a. worden bepaald of de geleidingssnelheid in die zenuw al dan niet normaal is. Met de standaard naaldelektrode worden potentialen geregistreerd van groepen spiervezels die aan een enkele zenuwcel vastzitten. Deze worden meestal aangeduid met de Engelse term 'motor unit potentialen'. Heel belangrijk voor de diagnostiek is dat gedenerveerde spiervezels spontane potentiaaltjes produceren waardoor de aanwezigheid van zenuwschade en vaak ook de localisatie daarvan kan worden vastgesteld.

Een speciale variant van het EMG heeft mij door alle jaren heen bijzonder geboeid. Het betreft hier het zogenaamde single-fiber EMG waarmee, binnen de intacte motor unit, activiteit van afzonderlijke spiervezels kan worden bestudeerd. Het is vooral de Zweedse klinisch neurofysioloog Erik Stalberg die deze techniek tot ontwikkeling heeft gebracht.

Ik leerde hem in 1973 kennen toen hil de eerste internationale cursus over single-fiber EMG gaf in het academisch zlekenhuis van de eeuwenoude universiteitsstad Uppsala. Met deze techniek, die wordt uitgevoerd met een naaldelektrode waarvan het afleldoppervlak een doorsnede heeft wan slechts 25 micron, kan 0. a. de impulsoverdracht van zenuwuiteinden naar individuele spiervezels worden bestudeerd. Het is de meest sensitieve elektrofysiologische techniek voor het vaststellen wan zlekteprocessen aan de neuromusculaire overgang. Het single-fiber 
ENC vergt ervaring en manuele vaardigheid, maar wordt ten onrechte vaak als moeilijk en zeer tijdrovend afgeschilderd. Ik heb er veel onderzoek mee verricht, zowel in het kader van de patientenzorg als bij weten. schappelijke studies.

\section{Evolked potentials}

In 1875 leidde de eerder genoemde Caton bij het konijn en bij de aap niet alleen spontane activiteit wan de hersenschors af, maar ook nam hij waar dat bij perifere stimulatie een afzonderlijke hersenpotentiaal kon worden gemeten.' Dit scort metingen kunnen we nu met verschillende typen stimuli (elektrisch, visueel, auditief) op niet invasieve wijze doen. Ze maken het mogelijk om de relatie tussen perifere sensibele zenuwen en de zintuigorganen enerzijds en het centrale zenuwstelsel anderzijds te onderzoeken. Om de door stimulatie opgewekte hersenpotentialen te kumnen herkennen tussen de spontane hersenactiviteit moet herhaaldelijk worden gestimuleerd, zodat de stimulusgebonden activiteit kan worden uitgemiddeld.

We spreken hierbij van "evoked potentials" en gebruiken eigenlijk nooit de Nederlandse vertaling "opgewekte potentialen", dit vanwege de tweeledige betekenis van opgewekt. De Vlamingen, im hum soms wat tweeslachtige hang naar taalpurisme, hebben thet over "geevokeerde potentialen". Met dit soort technieken kunnen stoornissen in de betreffende afferente baansystemen worden geconstateerd en deels aak gelow caliseerd. Een van de vele toepassingen heeft betrekking op patienten die 3 dagen na een reanimatie nog bewusteloos zijn. Het is gebleken dat wanneer bij elektrische stimulatie van een armzenuw, links zowel als rechts, geen corticale potentiaal wordt verkregen "terwijl van lagere niveaus nog wel signalen worden opgevangen, er geen herstel meer zal optreden, zodat verdere behandeling zinloos is.

\section{Diagnostiek met behulp van ultrageluid}

Dit onderzoek heeft een ander karakter dan de bovengenoemde technieken omdat er geen potentialen worden gemeten en ook niet wordt gestimuleerd. Binnen afdelingen klinische neurofysiologie gaat het hier vooral om het vaststellen van vernauwingen in slagaders die de hersenen van bloed voorzien, dit met behulp van geluid van een voor mensen onhoorbaar hoge frequentie, dat via een transducer wordt ingestraald. Ter plaatse van een vernauwing treedt cen toename van de 
bloedstroomsnelheid op. Het ingestraalde ultrageluid wordt weerkaatst door de rode bloedichaampjes, warbij het frequentieverschil tussen het ingestraalde en het teruggekaatste geluid een maat is voor zowel de snelheid als de richting van de bloedstroom. Dit fenomeen is genoemd naar Christian Doppler, die in 1842 de hypothese publiceerde dat wanneer een licht- of geluidsbron en een waamemer elkaar naderen, de wargenomen trillingsfrequentie toeneemt en dat deze afneemt wanneer zij zich van elkaar verwijderen. Op basis daarvan verklaarde hij het verschil in kleur bij dubbelsterren. ${ }^{2}$ Dat laatste bleek later niet te kloppen, maar de hypothese op zich wel. $U$ kunt dat regellmatig vaststellen aan de toonverandering wan de sirene van een passerende ambulance, maar voertuigen die zich zo snel verplaatsen kreeg men pas bij de komst van de stoomitrein. Onze landgenoot Buys Ballot, die sterk twijfelde aan de hypothese van Doppler, heeft in 1845 een hoornist op zo'n stoomtreim gezet en een aantal waarnemers met een absoluut gehoor langs de spoorbaan. Zij stelden vast dat de toon van een aangehouden noot bij nadering van de trein ongeveer een halve noot te hoog was en na passage evenveel te laag. ${ }^{2} \mathrm{Na}$ dit fraaie, zorgvuldig gedocumenteerde experiment, waarmee de juistheid van Doppler's hypothese onbedoeld was bewezen, duurde het nog een eeuw voordat men zich wan de talrijke praktische toepassingsmogelijkheden van dit principe bewust werd.

Toen mijn voorganger, professor Jan Mol, onze afdeling nog leidde konden we de grote arteriën binnen de schedel nog niet met ultrageluid onderzoeken en werden de halsarteriën "blind" geïnsoneerd. Hoewel ook op die manier belangrijke diagnostische resultaten werden bereikt, vormen de nadien ontwikkelde transcraniële Doppler (TCD) en het z.g. duplex-onderzoek een grote aanwinst. Bij dit laatste type onderzoek wordt tevens beeldvorming verricht, hetgeen mogelijk is doordat ultrageluid op grenswlakken tussen verschillende weefsels sterker wordt weerkaatst. Daardoor kan de plaats binmen het bloedvat waar de stroomsnelheid wordt gemeten nauwkeurig worden gekozen. Binnen onze afdeling heeft collega Werner Mess deze metingen uitgebouwd, hetgeen heeft geresulteerd in een verviervoudiging van het aantall ultrageluidsonderzoeken in de laatste 5 jar is. Bij operaties waarbij een halsslagader tijdelijk moet worden afgeklemd om verwijdering van een arteriosclerotische vernauwing mogelijk te maken (carotis-desobstructie), bewaken wij met TCD en EEG de doorbloeding en de functie van de hersenen. Ook wordt daarbij en erna met TCD vastgesteld of er al dan niet bloedpropjes de hersenen inschieten. Op een onderzoek naar deze 
micro-embolieën promoveerde collega Mess eerder dit jaar.

\section{Transcraniële magnetische hersenstimulatie}

Ik will niet alle typen onderzoek die door onze afdeling worden gedaan met u doornemen, maar toch nog een techniek de revue laten passeren die vooral in het achterliggende decennium is uitgegroeid tot een aparte tak van wetenschap. 3 Hierbij wordt gebruik gemalkt van magnetisme. Natuurlijk voorkomend magnetisme was al voor onze jaartelling bekend, maar pas omstreeks 1600 verscheen een publicatie over experimenten met magnetisme in ijzer en werd ook het idee van de aarde als magneet naar voren gebracht (Gilbert). Omstreeks 1820 werd het principe van de elektromagneet ontwikkeld (Ampere, Faraday).' In de techniek kent de magneet tegenwoordig talrijke toepassingen. Dat geldt ook binnen de geneeskunde. Een heel belangrijke toepassing is. beeldvorming door middel van magnetische resonantie, bekend onder de afkorting MRI. Hierbij worden op ingenieuze wijze gedetailleerde beelden van het inwendige van ons lichaam, waaronder de hersenen, verkregen door onze van huis uit magnetische waterstofkernen te onderwerpen aan kunstmatig opgewekte magneetvelden.

Veel minder complexe apparatuur wordt op KNF-afdelingen gebruikt om de motorische hersenschors via een boven het hoofd geplaatste magneetspoel kortstondig te stimuleren, dusdanig dat er spiercontracties in armen of benen optreden, waarvan de elektrische potentialen gemeten kunnen worden. Dat klinkt sommigen van u misschien wat griezelig in de oren, maar transcraniële magnetische stimulatie (TMS) is een ongevaarlijke en pijnloze methode warmee aandoeningen van motorische baansystemen in het centrale zenuwstelsel kunnen worden opgespoord. Het is natuurlijk ook mogelijk om door elektrische stimulatie van buitenaf de hersenen te stimuleren, maar dat is nogal pijnlijk en wordt in de kliniek alleen gebruikt in situaties waarbij de patiënt onder narcose is. Door onze afdeling wordt op die manier de functie van het ruggenmerg bewaakt bij langdurige operaties an de grote lichaamsslagader.

Wat de meeste mensen meer aanspreekt dan onze exacte metingen is dat met TMS ook psychische functies als spraakproductie, waarneming en geheugen beinvloed kunnen worden. Daarvoor is apparatuur ontwikkeld waarmee magnetische stimull in een ritmische opeenvolging kunnen worden toegediend. Daarmee kan o.a. een bepaalde 
thersenfunctie kortdurend worden geblokkeerd, zodat delen van de hersenschors die die functie controleren gelocalliseerd kunnen worden. Veel onderzoek is gedaan naar de mogelijkhelid om bij de behandeling van ernstige depressies de elektroshock therapie te verwangen door de nauwelijks belastende magneetstimulatie. Het is daarbij gebleken dat de frontale hersenschors een rol speelt bij de stemmingsregulatie. Ook zijn er a anwijzingen dat bepaalde vormen vari magneetstimulatie de plasticiteit van de hersenen kunnen bevorderen en daardoor bij sommige aandoeningen een therapeutisch effect zouden kunnen hebben. Dit is opzlenbarend, want tot nog maar 10 jaar geleden werd als vaststaand aangenomen dat volwassen hersenweefsel geen herstelcapaciteit heeft. Zoekt u op internet onder 'transcranial magnetic stimulation', dan krijgt $u$ vele duizenden vermeldingen. Naast waardevolle informatie zijn er helaas ook dubieuze bijdragen. Past u vooral op voor lieden die tegen betaling functies van uw centrale zenuwstelsel willen opkrikken. Charletannerie in de geneeskunde is van alle tijden. Zo hebben in de 19 de eeuw auteurs, sommigen met academische titels, boeken gepubliceerd met gedetailleerde afbeeldingen waarop te zien is waar in de hersenen alle denkbare hogere functies zijn gelocaliseerd. Deze schema's werden als absolute waarheid aan het publiek gepresenteerd, maar in werkelijkheid ging het bij deze z.g. "frenologie' om pure fantasie. Daar waar wij nu weten dat wij de corticale representatie van onze spieren stimuleren, localiseerden zij kwaliteiten als besluitvaardigheid, hoop, spiritualiteit. en zelfs onsterfelijkheid.

Overal in ons lichaam gaat activiteit van het zenuw-en spierstelsel gepaard met elektrische potentiaalschommelingen. Door de nauwe relatie tussen elektrische en magnetische verschijnselen betekent dit dat ons lichaam ook magnetische energie vertoont. De term hiervoor is "biomagnetisme". in een tijd waarin het nog volslagen onmogelijk was om dat te metern heeft men het bestaan hiervan kennelijk al woorvoeld. of de techniek van de klassieke magnetiseur iets met magnetisme van doen heeft valt echter te betwijfelen. Met uiterst gevoelige en kostbare toestellen is het tegenwoordig mogelijk om metingen te doen aan magneetvelden die door onze hersenactiviteit worden veroorzaakt. Daarmee kan informatie worden verkregen die in het EEG miet of onvoldoende aanwezig is. In Nederland zijn er van dergelijke apparaten slechts twee operationeel. Het magneto-encefalogram, waarbij gelijktijdig met zo'n honderdvijtig opnemers kan worden geregistreerd, is klinisch o.a. van belang woor het preoperatief localiseren van epileptische haarden. 
maar wordt vooralsnog woornamelijk gebruikt voor wetenschappelijke studies.

Dames en heren, in het kader van deze afscheidsrede kan ik niet ingaan op de andere technieken uit het neurofysiologisch repertoire. Voor zover ze op onze afdeling plaatsvinden zal ik ze kort memoreren: Functie-onderzoek van het autonome zenuwstelsel. Hiervoor dient een batterij onderzoeken gericht op het cardiowasculaire systeem. Elektroretinografle. Hierbij wordt gebruik gemaakt van een lenselektiode die op de oogbol wordt geplaatst en waarmee de potentialveranderingen van het netviles worden gemeten die ontstaan bij het toedienen van lichtprikkels onder fotopische en scotopische condities. Elektro-oculografie. Met naast de ogen geplaatste elektroden worden de potentiaalschommelingen gemeten die optreden wanneer de ogen volgens een vast protocol heen en weer worden bewogen. De rustpotentiaal van de retina leidt er namelijk toe dat de oogbol in elektrisch opzicht een dipool is.

Temperatuurdrempel metingen. Volgens twee werschillende protocollen worden met behulp van een Peltier-element nauwkeurig in te stellen temperatuurstimuli toegediend, waarbij de onderzochte aangeeft welke stimuli wel en welke niet worden waargenomen. Op deze wijze worden aan handen en voeten drempels voor de waameming van warmte en koude wastgesteld. Met deze techniek heeft onze afdeling woor het eerst afwijkingen gewonden die wijzen op het bestaan wan een dunne-vezel neuropathie bij een subgroep van patienten met de ziekte sarcoidose.

\section{Wetenschappelijk onderzoek.}

Ik ben ooit gepromoveerd op een proefschrift over effecten van foliumzuur toediening bij patienten met eplepsie. Daarbij is naar allerle parameters gekeken, maar reeds in dat kader kwam mijn belangstelling voor elektromyografisch onderzoek duidelijk naar woren. Ik heb daar oa. een bijzondere vorm vam zenuwgeleidingsonderzoek toegepast. een zagenaamde 'collision' techniek waarmee een beeld werd verkregen van het spectrum van geleidingssnelheden van motorische axonen binnen een zenuw. Nadien is elektromyografie mijn specifieke aandachtsgebied gebleven, zowel in het kader van de patientenzorg alls in wetenschappelijk opzicht. Daarbij heeft het eerder genoemde single-fiber EMG een belangrijke rol gespeeld, o.a. in studies met dr. Marc De Baets, die heden 
morgen ook behoorde tot de sprekers op het symposium. Het bijzondere wan single-fiber EMG is dat er op minimaal unvasieve wijze informatie mee kan worden verkregen over de microfysiologie van de motor unit. In diverse wetenschappelijke studies, zowel bij patienten met primaire neuromusculaire transmissiestoornissen als bij proefdierent waarbij aen dergelijke stoornis was opgewekt, hebben we van die mogelijkheid gebruk gemaakt.

Maar ook bij andere neurologische aandoeningen hebben we onze inz chten met behulp van single-fiber EMG kunnen verdiepen. Onlangs nog hebben wij ermee kunnen aantonen dat bij de acute idiopathische polyneuropathie, bekend als de ziekte van Guillain-Barré, de verlammingsverschijnselen niet alleen wordt bepaald door geleidingsblokkades als gevolg van demyelinisatie en door verloren gaan van zenuwvezels, maar dat functiestoormissen van de neuromusculaire overgang en van de axonmembraan aan die verlammingsverschijnselen bijdragen. Het niet structurele karakter van deze stoornissen vormt een verklaring voor die ziektegevallen waarbij een indrukwekkende spierzwakte zich opmerkelijk snel herstelt.5

Overigens kunnen ook met standaard KNF-technieken waardevolle studies worden verricht. Een van die standaard technieken is het spieronderzoek met behulp van de klassieke concentrische naaldelektrode. Wanneer deze in een ontspannen spier is geplaatst wordt er normaliter geen activiteit geregistreerd. Er zijn echter met name genetisch bepaalde aandoeningen waarbij er uitbarstingen van spontane activiteit optreden. Het betreft hier massale ontladingen van spiervezels met een genetisch bepaalde afwijking van hun membraan waardoor ze vooral bij lichte mechanische prikkeling, zoals tikken op de spier of kleine naaldverplaatsingen, buiten de wil van de betrokkene om geactiveerd worden. Het klinische effect van deze overprikkelbaarheid is dat de patiënt een eenmaal aangespannen spier maar moeilijk kan ontspannen hetgeen niet alleen lastig is, maar ook tot gevaarlijke situaties kan leiden. Deze vorm wan splerverkramping heet myotonie.

Er bestaat een dominant overerfende ziekte waarbij myotonie gepaard gat met het durner en zwakker worden van de spieren. Al voor mijn benoeming in Maastricht had ik bij een familie met deze myotone dystrofie vastgesteld dat alle patiënten die myotone verschijnselen ver toonden ook een fors gestoorde zenuwgeleiding hadden. Bij sommige jongere familieleden was de zenuwgeleiding vertragd zonder dat er myotone ontladingen werden gevonder. Erfelijkheidsonderzoek, ver- 
richt voordat de DNA afwijking was ontdekt, wees er al op dat het hier geen toevallige combinatie van twee verschillende erfelijke ziekten betrof, maar dat de zenuwaandoening zijn oorsprong moest hebben in de directe nabijheid van het gen voor dystrofia myotonica. ${ }^{6}$ Dit wekte verbazing omdat een polyneuropathie met die genlocalisatie nooit eerder was gevonden. Inmiddels zijn onze bevindingen meer dam eens met DNA technieken bevestigd.7

Er is nòg iets bijzonders bij deze familie. Bij de aangedane leden van de jongste generatie kon doorgaans rond het twintigste levensjaar ook de myotonie worden aangetoond, maar de polyneuropathie bleef het klinische beeld overheersen en er waren kenmerken die bij de klassieke dystrofia myotonica in latere generaties eigenlijk nooit wordt gezien. Zij toonden o.a. een bovengemiddelde intelligentie en doorzettingsvermogen, tot uiting komend in het succesvol afronden van academische studies. Er lijkt dus een verschuiving in het ziektebeeld te zijn opgetreden. Bij myotone dystrofie was wel eerder een generatiegebonden verschuiving van het ziektebeeld opgevallen, maar dan in de zin van het ontstaan van allengs zwaardere afwijkingen. Dit verschijnsel, dat met de term "anticipatie' wordt aangeduid, is lange tijd voor een drogbeeld gehouden. De neuroloog Chris Höweler, met wie ik vele Jaren in het azM heb mogen samenwerken, heeft echter als eerste onomstotelijk aangetoond dat het een reëel fenomeen is. ${ }^{8}$

Al vrij snel na zijn desbetreffende publicatie hebben de genetici een verklaring voor die anticipatie gevonden. Myotone dystrofie bleek niet veroorzaakt te worden door een kleine locale vergissing in de DNA structuur, zoals bij veel andere erfelijke aandoeningen, maar door een sterk toegenomen therhaling van een setje van drie DNA bouwstenen, dat in opeenvolgende generaties steeds langer pleegt te worden. Daarmee kon de toenemende ernst van het ziektebeeld worden verklaard. Maar. zoals in de wetenschap vaak het geval is, liep men, na het enthousiasme over de nieuwe ontdekking, tegen nieuwe problemen aan. De afwijkend sterke herhaling van tripletten bleek zich te bevinden in een stuk DNA van waaruit helemaal geen aanmaak van enig elwit plaatsvindt, zodlat de vraag is hoe dan de ziekte tot stand komt. Een mogelijkheid is een effect van de locale witwas op nabigelegen gebieden die well voor eiwitten coderen. Een andere theorie is dat het afwijkende RNA, dat wordt geproduceerd vanuit het pathologisch uitgegroeide DNA fragment, de functie van lichaamscellen ondermijnt. Dit abnormalle RNA zou ook de functie van op afstand gelegen genen kunnen verstoren. 9 Dat zou dan 
een verklaring wormen woor het feit dat bij myotone dystrofie niet alleen het spierstelsel, maar waak ook andere organen zijn aangedaan. Zo krijgen deze patienten vak een troebeling van de ooglens, hartritmestoornissen, stoornissen van de sexuele functies en slaapzucht.

Inmiddels heeft zich een belangwekkende ontwikkeling voorgedaan. Recent is ontdekt dat in de regio van chromosoom 19 waar zich het dystrofia myotonica gen bevindt (19913), ook het gen woor het eiwit periaxine is gelegen. Van periaxine is aangetoond dat het essentieel is voor de aanmaak van het myeline dat de perifere zenuwvezels bekleedt. Een gestoorde myeline aanmaak veroorzaakt vertraging van de zenuwgeleiding en uiteindelijk verloren gaan van zenuwvezels. Hulp van genetici zal nodig zijn om na te gaan of hier inderdaad de verklaring ligt woor de unieke combinatie van myotone dystrofie en erfelijke polyneuropathie in de door ons beschreven familie.

Maar ondertussen heeft zich binnen deze familie alweer een nieuwe component van het ziektebeeld gemanifesteerd die niet eerder bij myotone dystrofie is beschreven. Binnen een periode van 5 jaar kregen 3 aangedane vijftigers, onafhankelijk van elkaar, een of enkele plotseling optredende verwardheidstoestanden gevolgd door bewustzijnsdalingen. Bij een van hen ontstond zelfs een periode van volledige bewusteloasheid. Omdat het ziektebeeld steeds begon met koorts werd aanvankelijk bij alle drie aan een hersenontsteking gedacht, maar dat kon bij nader onderzoek nooit worden bevestigd. De EEG's die wij hebben gemaakt toonden bij alle drie eenzelfde beeld: zware asymmetrische afwijkingen die pas in de loop vani weken normaliseerden, terwijl de patiënt vaak al na enkele dagen klinisch hersteld leek te zijn.

Het ziektebeeld toont enige gelijkenis met een familiaire worm van migraine waarbij halfzijdige verlammingsverschijnselen optreden. Bij de hemiplegische migraine gaan de bewustzijnsstoornissen ook met koorts gepaard en worden overeenkomstige EEC afwijkingen gevonden. Maar onze patiënten lijden niet aan migraine en wij konden bij hen ook geen verlammingsverschijnselen vaststellen. De DNA afwijking voor familiatre hemiplegische migraine ligt, evenals dat voor myotone dystrofie, op chomosoom 19, maar dan op de andere arm van dat chro. mosoom en daardoor genetisch gezien millen ver weg.

Dames en heren, zoals dit voorbeeld reeds aangeeft, wetenschappelijk onderzoek roept steeds nieuwe vragen op. Het is ook steeds meer een kwestie van samenwerking met andere disciplines. Ik wil dit onder- 
werp afsluiten met de constatering dat ik met veel genoegen heb gewerkt aan wetenschappelijke publicaties met collegae uit de neurologie, immunologie, anesthesiologie, proctologie, urologie, orthopedie, revalidatie, anatomie, genetica, bewegingswetenschappen "humane biologie, longziekten en epidemiologie. In veel studies heb ik samengewerkt met onze klinisch fysicus, dr.ir. Jos Reulen.

\section{Onderwijs}

De medische faculteit in Maastricht heeft zich van meet af aan, en als eerste in Europa, geprofilleerd met het probleemgestuurd onderwijs (PGO). Als onderdeel daarvan worden studenten vanaf het eerste jaar via blokboeken geconfronteerd met medische problemen. Daarmee moeten zil zich wia zelfstudie en groepsbesprekingen inzicht verwerven in de anatomische, fysiologische en medische aspecten van de betreffende casus. Zij werken daarbij in kleine groepen die door een tutor wor. den begeleid. In principe was de tutor uitsluitend bedoeld als bewaker van het groepsproces en werd inhoudelijke kennis overbodig geacht. Dat een dergelijke rol ook moest worden vervuld door hooggekwalficeerde, duur betaalde medisch specialisten heb ik altijd als onbevredigend ervaren. Waar medisch specialisten voor deze onderwijstaak worden ingezet is het naar mijn ervaring van veel belang dat zij hun inhoudsdeskundigheid daarin kunnen benutten en daarmee de studen ten doelgericht kunnen stimuleren. Het is een goede zaak dat men daar allengs meer oog voor heeft gekregen. Colleges, vaak aangeduid als lezingen, worden mondjesmaat gegeven. Daarnaast worden praktische vaardigheden getraind en is er een scalla aan keuze-onderwijs. Hoewel de klinische neurofysiologie binnen de geneeskunde studie witeraard een bescheiden rol speelt, participeren de stafleden in al deze onderwijswormen.

Slechts een beperkt deel van de week is er onderwijs, want de opvatting is dat de studenten voldoende tijd moeten hebben om zelf informatie te vergaren. Velen van hen lijken een groot deel van die tijd aan andere zaken te besteden, maar hoe het ook zij, het systeem is succesvol, hetgeen o.a. blijkt uit het feit dat het tot op zekere hoogte is overgenomen door de zusterfaculteiten.

Immiddels wordt onvermoeibaar aan onderwijsvernieuwingen gewerkt. Zo is men met ingang van dit studiejaar het klinisch onderwijs binnen het Academisch Zlekenhuis Maastricht gaan vervroegen, o.a. door het instellen van 'onderwijspoli's' woor derdejaars studenten. 
Het aantal studenten dat gebruik gaat maken van de werkplaatsfunctie van het azM zal op zeer korte termijn enorm toenemen. De nieuwe koers vergt een uitbreiding van ruimtelijke voorzieningen en brengt een aanzienlijke toename van de onderwijsbelasting van de medische staf met zich mee. Hoe een en ander, bij een gelijk blijvend aantal medisch specialisten, moet worden opgelost is nog niet voor ledereen duidelijk.

\section{De opleiding in de Klinische Neurofysiologie}

Toen ik zelf werd opgeleid tot neuroloog, dat was in de jaren 1966 tot 1971 in het toenmalige Wilhelmina Gasthuis te Amsterdam, was in de standaard opleiding een half jaar klinische neurofysiologie inbegrepen. Dat halfjaar kwam altijd pas tegen het eind aan bod waardoor de KNF tijdens de hele opleiding een oncuidelijk en kennelijk heel moeilijk onderdeel van het wak leek te zijn. Wilde je uiteindelijk tach de bevoegdheid kriggen dat onderdeel van het vak gehonoreerd uit te aefenen dan moest je daarvoor een aantekening halen, hetgeen in paviljoen 2 wan het WG betekende dat je elders een opleidingsperiode van nogmaals zes maanden moest zien te bemachtigen.

Toen in latere jaren bleek dat vrijwel alle neurologie-assistenten die aantekening wilden halen, werd de klinische neurofysiologie een integraal onderdeel van de opleiding tot neuroloog, met een duur van 15 maanden. Degenen die t.z.t. vooral KNF zouden willen bedrijven werd de mogelijkheid geboden om 27 maanden van de 6-jarige opleiding aan dat vakgebied te besteden. Er werd op basis daarvan binnen de opleiding tot neuroloog een 'hoofdwak Klinische Neurologie' en een 'hoofdvak Klinische Neurofysiologie' onderscheiden, waarbij de opleiders voor die hoofdvakken in eerste instantie verantwoordelijk waren voor hun eigen opleidingsdeel en gezamenlijk voor de neurologie-opleiding als geheel. Vrijwel alle KNF-opleiders hebben deze in 1991 van kracht geworden opleidingsstructuur als zeer bevredigend ervaren. Binnen die structuur heb ik hier in Maastricht ook altijd bijzonder plezlerig en constructief met professor Jaap Troost samengewerkt. Dat in enkele klinieken de samenwerking niet optimaal was vond zijn oorzaak in persoonlijke ver* houdingen en niet in de opleidingsstructuur. Maar ook bij de specialistenopleidingen winden voortdurend vernieuwingen plaats. Op werzoek van het Centraal College Medische Specialismen hebben de Vereniging voor Neurologie en de Vereniging voor Klinische Neurofysiologie enkele Jaren geleden een nieuw opleidingsplan gemaakt. Dit is sinds kort van kracht en gaat uit van een rompopleiding van 4 jaar en een vervolgop. 
leiding van 2 jaar, dit wooruitlopend op een te verwachte Europese regeling. Binnen de rompopleiding vallen 12 maanden klimische neurofysiologie. In de laatste twee jaar kan desgewenst een aanvullende KNF. stage worden gepland of kan worden gekozen voor het hoofdvak klini. sche neurofysiologie.

Het valt te betreuren dat het Centraal College, in een streven naar eenvormigheid van specialistenopleidingen, heeft besloten de hoofd. vakstructuur niet te continueren. Het heeft daarom aan de beide wetenschappelijke verenigingen gevraagd om met een nieuw woorstel te komen, hetgeen heeft geleid tot onderlinge controversen. Veel klinisch neurofysiologen achten de belangen van hun vakgebied dermate bedreigd dat een al bij eerdere spanningen naar voren gekomen wens voor een eigen specialisme weer actueel is geworden. Uitzonderlijk is die wens niet, want de klinische neurofysiologie komt als een afzonderlijk specialisme in diverse landen voor en is ook als als zodanig erkend binnen de Europese Unie.

De oudste generatie werkzame klinisch neurofysiologen, waartoe ik vandaag nog net behoor, heeft zelf niet méér KNF-opleiding gehad dan ledere neuroloog die naast zijn klinische praktijk de KNF beoefent. Voor het overige hebben zij zichzelf verder in deze discipline moeten bekwamen. Het laat zich begrijpen dat zij die het vak ter harte gaat opvolgers willen hebben met een betere en uitgebreidere opleiding dan waarmee zij het zelf hebben moeten doen, dit temeer daar dat vak zich sterk heeft ontwikkeld.

Hoe de opleidingsstructuur er ook zal gaan uitzien, voor mij is het altijd duidelijk geweest dat klinische neurofysiologie weliswaar deels een superspecialisatie is, maar dat het daarnaast een basisvak van de neurologie is. Daarom hoort het, op zijn minst voor een aanzienlijk deel, vroeg in de opleiding tot neuroloog thuis. Een praktisch winstpunt hier. van is dat de assistent gedurende de rest van de opleiding de verslagen van het neurofysiologisch onderzoek veel beter begrijpt en ook meer doelgericht onderzoek kan aanwragen. Onze evvaring is dat cursorisch onderwijs weinig effect sorteert en dat werkelijk inzicht in de diverse onderzoeken pas ontstaat wanneer de assistent die zelf gat doen en beoordelen. Daarenboven blijkt ervaring op EMG-gebied vaak een aanzienlijke lacune in de kennis van spier-en zenuwaandoeningen te vullen, iets dat vooral tijdens de polliklinische stages zijn vruchten afwerpt. ook de meerderheid van de assistenten die ik in eigen huis en bij 
visitaties wan andere opleidingsafdelingen daarover heb bevraagd was deze mening toegedaan. Mij lijkt het optimaal om met klinische neurofysiologie ergens in het zde jaar te beginnen.

\section{De afdeling Klinische Neurofysiologie van het azM}

Mijn voorganger, professor lan Mol, heeft het destijds aan mij overgelaten orn de afdeling woor het nieuwe zlekenhuis te plannen. Na veel vergaderingen en touwtrekken en ondanks kaasschaafreducties is een moole afdeling tot stand gekomen, waar wij efficient en met plezier hebben kunnen werken. Een grote weerstand die ik heb moeten overwinnen was gericht tegen onze eis dat de kamers van de stafleden binnen de functie-afdeling gelocaliseerd moesten worden. Want de vaste stelregel was dat dokters met hun secretariat in een stafareaal moeten zitten en van daaruit naar de polikliniek, de verpleegafdeling of de operatiekamer gaan. Voor een goede uitoefening van ons wak is echter een continue interactie tussen dokters, laboranten, technische medewerkers en secretariaat noodzakelijk. Alle medewerkers van mijn afdeling wil ik hier graag bedanken woor de uitstekende samenwerking. die bij sommigen al in het oude Annadal-ziekenthuis begon. Mede dankzij hun inzet zijn we erin geslaagd om niet alleen werk van hoge kwaliteit te leveren, maar ook om de wachttijden voor onderzoeken tot hooguit 2 weken te kunnen beperken en een snelle verslaggeving te realiseren. I heb dit altijd belangrijk gevonden omdat op deze wijze het KNF-onderzoek een optimale klinische bijdrage levert. Want het moge duidelijk zijn dat wij weliswaar allerlei potentialen meten, maar dat het er daarbij om gaat de diagnostiek en behandeling van patienten zo doeltreffend mogeilik te ondersteunen.

Helaas heeft de procedure voor mijn opvolging een forse vertraging opgelopen. Met het tijdelijk wegvallen vam een derde van de specialistenformatie wordt een zware wissel getrokken op de overblijuende stafleden. Het is dan ook van groot belang dat de sollicitatieprocedure met voortvarendheid wordt woortgezet.

Ondertussen is het duidelijk dat binnen de onderzoeksinstituten van de faculteit en het topreferentie-gerelateerde onderzoek van het ziekenhuis zich woor de klinische neurofysiologie uitstekende mogelijkhe* den voordoen om zich wetenschappelijk te profileren. Ik wens mijn collega's daarbij veel succes. 
Aan het eind vam mijn rede gekomen wil ik tenslotte de Raad van Bestuur van het Academisch Ziekenhuis Maastricht en de besturen van de Uniwersiteit en wan de Faculteit der Geneeskunde bedanken woor het gedurende vele jaren in mij gestelde vertrouwen.

Ik heb gezegd. 


\section{Litteratuur}

1. Bates JAV. Five Pioneers in the study of the Electrical Activity of the Brain. wth International Congress of Electroencephalography and Clinical Neurophysiology, London, 1985.

2. Jonkman Ef, Doppler research in the nineteenth century. Ultrasound Med Biol $1980 ; 6: 1-5$.

3. Hallett $M$. Transcranial magnetic stimulation: a revolution in elinical neurophysiology. I Clin Neurophysiol 2002;19:253-254.

4. Verschuuren J, Spaans F, De Baets M. Single fiber electromyography in experimental myasthenia gravis. Muscle Nerve 1990;13:485-492.

5. Spaans F, Vredeveld IW. Morré HHE, Jacobs BC, De Baets MH. Dysfunction at the motor end-plate and axon membrane in GuilainBarré syndrome. A single-fiber EMG study. Muscle Nerve 2003: 27: 426-434.

6. Spaans F, Jennekens FGI, Mirandolle J.F., Bijlsma IB, de Gast GC. Myotonic dystrophy associated with hereditary motor and sensory neuropathy: Brain 1986;109:1149-1168.

7. Brunner $\mathrm{HG}$, Spaans F, Smeets $\mathrm{HJ}$, et al. Genetic linkage with chromosome 19 but not chromosome 17 in a family with myotonic dystrophy associated with hereditary motor and sensory neuropathy. Neurology 199\%:41:80-84.

8. Höweler CJ, Busch HFM, Geraedts JPM, Nlermeljer MF, Staall A. Anticipation in myotonic dystrophy: fact or fiction? Brain 1989;112: 779-797.

9. Tapscott AJ, Thornton CA. Reconstructing myotonic dystrophy. Science $2001 ; 293: 816-817$. 
